\title{
Article \\ Do Creators of New Markets Meet SDGs? Analysis of Platform Companies
}

\author{
Inga Mezinova ${ }^{1}$, Milena Balanova $^{1} \mathbb{D}$, Oleg Bodiagin ${ }^{1} \mathbb{D}$, Elima Israilova ${ }^{1}$ and Elmira Nazarova ${ }^{2, * \mathbb{C}}$ \\ 1 Department of World Economy and International Politics, Rostov State University of Economics, \\ 344002 Rostov-on-Don, Russia; dayainga@gmail.com (I.M.); ipd.rsue@gmail.com (M.B.); \\ oleg.bodyagin@gmail.com (O.B.); elimarsue@mail.ru (E.I.) \\ 2 Graduate School of Service and Trade, Institute of Industrial Management, Economics and Trade, \\ Peter the Great St. Petersburg Polytechnic University, 195251 St. Petersburg, Russia \\ * Correspondence: nazarova_ea@spbstu.ru
}

Citation: Mezinova, I.; Balanova, M.; Bodiagin, O.; Israilova, E.; Nazarova, E. Do Creators of New Markets Meet SDGs? Analysis of Platform

Companies. Sustainability 2022, 14, 674. https://doi.org/10.3390/

su14020674

Academic Editor:

Fabrizio D'Ascenzo

Received: 30 November 2021

Accepted: 5 January 2022

Published: 8 January 2022

Publisher's Note: MDPI stays neutral with regard to jurisdictional claims in published maps and institutional affiliations.

Copyright: (C) 2022 by the authors. Licensee MDPI, Basel, Switzerland. This article is an open access article distributed under the terms and conditions of the Creative Commons Attribution (CC BY) license (https:// creativecommons.org/licenses/by/ $4.0 /)$.

\begin{abstract}
The platform economy is the embodiment of the activities carried out by its influential players, which by their very nature are new markets, facilitating the matching of suppliers and customers. A new market entails access to or even joint use of underused assets, provision of new working places, and simplification of human life with online transactions and services, which serves the assumption that the platform economy is able to undertake sustainable development and may meet a number of the UN's Sustainable Development Goals (SDGs) introduced in 2015. First, this paper aims to study whether the platform business model entails sustainability as its integral core concept. Second, it attempts to assess if platform companies from two selected industries-ridesharing services and EdTech-meet SDGs comparably better than their predecessor linear companies in transportation and education. The study carries out an empirical analysis of eight companies. The results indicate that platform companies demonstrate a relatively lower commitment to SDGs compared to linear transnational firms, which can be explained by the level of maturity of platform companies and their still mostly non-public nature.
\end{abstract}

Keywords: platform company; platform economy; linear company; sustainable development goals; sustainability

\section{Introduction}

Back in 2000, 189 countries signed the Millennium Declaration, committing to achieve a set of 8 goals: (1) eradicate extreme poverty and hunger, (2) achieve universal primary education, (3) promote gender equality and empower women, (4) reduce child mortality, (5) improve maternal health, (6) combat HIV / AIDS, malaria, and other diseases, (7) ensure environmental sustainability, and (8) develop a global partnership for development, by 2015. These became known as the Millennium Development Goals (MDGs) [1]. Later on, in 2008, the United Nations launched the Business Call to Action (BCtA) initiative, which was aimed at accelerating progress towards the above stated goals in low and middleincome nations with the help of private sector, which at that time was mostly regarded as a non-priority stakeholder [2].

In 2015, within the 2030 Agenda for Sustainable Development, adopted by all UN member states, 17 Sustainable Development Goals (SDGs) were introduced as an urgent call to action by all countries. Seventeen goals set 169 global targets with deadlines and 232 global indicators, which would review the progress of SDG actions against global targets. The introduction of goals was preceded by a rather long period of negotiations, consultations and dialogues between national governments, representatives of the business community, non-governmental organizations, and educational and public institutions [3,4]. For the first time since the initiation of the MDGs, multinational companies have taken a real, active participation in the process of formulating both the goals themselves, and 
the tasks faced by-among other things-international companies for achieving these goals, thereby giving additional validity and legitimacy to all the efforts of the global community [5]. That year more than 70\% of "big" international companies announced their commitment to the SDGs by amending their operations and strategic plans in the shortand medium-time period [6].

Theoretical and empirical research in the field of international business and, in part, international trade policy, traditionally rarely assesses and measures the changing role of transnational companies in global sustainable development issues-in particular, in agenda setting, SDG development, and the creation of intersectoral partnerships. In most cases, research focuses on macro-level analysis [7-9] and covers the current state of multinational companies' commitment to SDGs within individual sectors, e.g., patent applications [10], linkages between SDG targets and companies' value chain operations [11]; linkages between companies' subsidiaries and headquarters' SDG vision [12], corporate sustainability ethics [13] or a general overview of the issue [14].

As for new types of companies with new explosive business models that emerged in the era of digitalization and their relationship with SDGs, the research in this field is actively developing. However, they cannot yet provide a comprehensive and complete understanding of the subject area under study. This is partly due to the fact that the very nature of these new actors in the global economic space is still the subject of intense discussion. For example, in this work, we use the concept of platform companies, but related terms are used by other authors, such as sharing economy companies, collaborative economy entities, i-business firms, etc. This, however, does not prevent authors using different terms from being in a certain consensus that we are dealing with close and related categories, and when considering issues not directly related to the development of basic definitions, such as the topic of this study, from considering these terms as interchangeable.

Reviewing the issues raised and the results introduced by the scientific community in terms of platform businesses and SDGs revealed that the topic of the relationship between platform companies and the goals masks generic challenges. The results of the research are complicated and can be different depending on: (a) separate SDGs' alignment with sustainability with regard to digital and platform economies, as well as SDGs taken for analysis (each SDG has/does not have criteria in terms of a digital perspective); (b) the typology of the platform companies, and the type of platform business model in particular, selected for the analysis, and (c) the type of ICT prevailing in the platform.

Fuster Morell, Espelt and Cano primarily concentrated on a digital perspective of SDGs [15]. The researchers postulated that the SDGs themselves do not promulgate digitalization as an effective tool of knowledge and asset accessibility, or for reaching equality. This suggests that SDGs should improve their digital perspective to intertwine better with sustainable platforms [15]. Their second step was to track if platform companies meet SDGs. Fuster Morell, Espelt and Hidalgo set the tasks of comparing several platform economy models, namely cooperative models, open commons models and platform capitalism models, and their connections with SDGs [16]. The scholars concluded that the platform model closest to the SDGs is commons-oriented. Another important finding that they introduced was the reasons behind why platform companies are not responding in full to SDGs, the first being the limited digital perspective of the SDGs in their own definitions, the second-the immaturity of the platform economy itself, which needs time to uncover all its strengths and meet the challenges mentioned in the SDG context. The sustainable influence of Industry 4.0 (I4.0) technologies for meeting SDGs was also helpful in shaping the current research [17]. Researchers concluded that the majority of I4.0 technologies positively influence the 2030 Agenda, and only very few elements are expected to negatively influence the goals related to reducing inequality (SDG10). Another work helped to touch upon the potential of collaborative business models, which is also concerned with meeting SDGs [18]. The authors rested on the connectedness of three concepts-sustainability, business model innovation and cross-sector collaboration-on the condition that if they are methodologically elaborated at the governmental level, they could lead to real-effect sus- 
tainable businesses. Few studies have been dedicated to the examination of sustainability strategies of global firms by industry [19].

Attempts have been made to uncover the motivations that force platform companies to demonstrate and contribute to serving society, including in the context of SDGs [20].

Realizing the potential and the increasing impact of new business models on the economy, society and the environment, a number of authors have made efficient attempts to assess and open a discussion on developing a methodology for assessing the impact of platform (sharing/collaborative) economies on progress towards achieving SDGs [21].

It seems that in order to increase the understanding of the role of platform companies in achieving Sustainable Development Goals, a complementary assessment of their commitment to SDGs would be a great contribution. Commitment reflects the orientation of the company's senior management towards achieving SDGs, no matter what motives they are guided by. The manifestation of commitment is an indicator of the aspiration to achieve this goal and, to a certain extent, a guarantee of a positive effect in the future-even if at the current time these achievements seem insignificant. In the future, one can evaluate the effects and track the dynamics of this commitment. However, conducting such an assessment faces a more fundamental challenge - the development of its principles and methodology.

On the one hand, the assessment methodology should be universal-platform companies cannot and should not, in our opinion, be considered in isolation from other business entities as their contribution to achieving universal values, namely SDGs, is evaluated. On the other hand, in order to understand the specifics or the path along which relatively "young" business entities are moving, it is useful to understand to what extent they can claim to be the leaders in the matter of contributing to SDG achievements. With that in mind, a comparative analysis of platforms with their "older" and more experienced counterparts is necessary.

The aim of this paper is to have a deeper look at the general tendency of platform companies, crowding the world market and displacing linear businesses, and their impact on meeting the UN's Sustainable Development Goals. The relevance of the topic lies in the scarce and fragmented findings of scholars in assessing the basic readiness/commitment of platform companies to following SDG targets, as well as to investigate if platform companies-being newer, and thus assuming that they are "smarter" and better functioning-fail to assume responsibility, leading more to issues such as environmental degradation, inequality and social injustice compared to traditional players in the market.

Considering the above stated research gap, we addressed these research questions by: (1) conducting a selection of platform companies in order to pick up illustrative cases for evaluating the commitment of platform companies to SDGs; (2) conducting a comparative analysis of existing approaches to assess the contribution of companies towards the implementation of SDGs; (3) proposing a methodological approach to determine the potential of companies to contribute to SDG achievements by assessing the degree of their commitment to SDGs; (4) based on the proposed methodology, conducting a comparative analysis of the degree of commitment of linear and platform companies based on selected cases.

Our findings show that the level of platform firms' commitment to SDGs in two selected industries, belonging to the secondary and tertiary sectors, is less explicit than that of their linear "twins", suggesting a broad area for discussion and interpretation of this phenomenon.

\section{Materials and Methods}

Explaining platform firms' commitment to SDGs is challenging, not least because it has no recognized and widely used frameworks.

This section focuses on the main approaches that are used in this field and explains how we obtained the data.

Searches for the information and indicators, that along with the strategy, goals and interactions with stakeholders would also the reflect the organization's activities in terms 
of their social responsibility and commitment to sustainable development, revealed that all the entities in our study did not follow the same reporting practices. Although the pressure for sustainability reporting is growing under the influence of global trends, it is still a non-obligatory practice [22].

However, the changing behavior of investors and public opinion towards more responsible capital allocation decisions beyond just financial reasons, requires better clarity and confidence in the Environmental, Social and Corporate Governance (ESG) agenda disclosed by a company.

Unlike with financial reporting standards, guided by the International Accounting Standards Board (IASB), whose approach is generally accepted in more than 140 countries, the international community is still at a crossroads in developing a unified and globally accepted system for corporate disclosure of sustainability commitment. As of 2020, there were more than 100 multi-stakeholder initiatives in this field, involving 5181 constituent members [23].

Still, several initiatives in this field have gained the greatest recognition.

1. The Global Reporting Initiative (GRI)

The GRI was founded in 1997 as the initiative of two non-profit organizations (CERES and the Tellus Institute) to create "the first accountability mechanism to ensure companies adhere to responsible environmental conduct principles, which was then broadened to include social, economic and governance issues" [24]. In 2016, the GRI introduced the first global standards for sustainability reporting that reflect corporate responsibility for their impacts and contributions to a sustainable future.

2. The Climate Disclosure Standards Board (CDSB)

The CDSB was founded in 2007 as an international consortium of business and environmental NGOs "to provide investors with decision-useful environmental information via the mainstream corporate report, enhancing the efficient allocation of capital" [25].

3. The International Integrated Reporting Council (IIRC)

The IIRC was founded in 2010 by The Prince of Wales' Accounting for Sustainability Project, the Global Reporting Initiative and the International Federation of Accountants in order to "consolidate existing reporting practices to move towards a reporting framework that provides the information needed to develop the global economic model to meet the challenges of the 21st century" [26]. In other words, this reporting standard is aimed at demonstrating how financial and non-financial performance connects with the environmental, social and governance contexts within which every firm operates.

4. Sustainability Accounting Standards Board (SASB)

The SASB was founded in 2011 as a nonprofit organization "to help businesses and investors develop a common language about the financial impacts of sustainability prospects". Unlike all the other initiatives, the SASB gives guidelines for the disclosure of sustainability information which is financially significant and industry-specific, thus making it purposefully relevant for investors [27].

In June 2021, the IIRC and SASB merged to form the Value Reporting Foundation (VRF), with the goal of leading to a "shared understanding of enterprise value-how it is created, preserved or eroded over time" for both businesses and their stakeholders [28].

This is another attempt to clarify and simplify the corporate reporting landscape; however, the initiative still has a long way to go in order to become a unified global reporting standard. Along with that, in November 2021 during the UN Climate Change Conference (COP26), the IFRS Foundation Trustees announced the formation of the International Sustainability Standards Board (ISSB)_-“a comprehensive global baseline of high-quality sustainability disclosure standards to meet investors' information needs" [29].

As all the revised ESG reporting standards are still far away from being as unified and comprehensive as the financial reporting standards, we relied on the SDG Impact Standards, 
developed by SDG Impact-a flagship initiative of the United Nations Development Programme (UNDP). Being driven by the UN in total accordance with the initial SDGs' ambition, these standards are undergoing public consultations, "including the investment and business community, civil service organizations, organizations expert in human rights and the rights of indigenous peoples, other United Nations bodies as initiatives, and relevant industry groups" [30].

The most advantageous distinguishing feature of the SDG Impact Standards is that, unlike all the other initiatives we considered earlier, these standards were developed in order to make them a universal, available as a voluntary, self-assessment guide. This made them the perfect framework for use in our study, considering that this approach enables the usage of open-access data on firms' performances.

We used the second public consultation draft of the SDG Impact Standards for Enterprises (as of March 2021 guidelines), following their criteria [31].

We examine whether entities disclose information concerning SDG commitment in open-access sources-annual statutory reports, official corporate statements and initiatives (that can be traced on the company's website), and CEO interviews. Measures of firms' transparency were based on disclosure quantity, rather than quality - and this is true of the commitment issues, which are still not properly formalized-found in the literature on political science and international business [32,33]. We follow this formal counting approach in incorporating an informativeness dimension: disclosure of the number of initiatives towards committing to SDGs allows responsible investors to compare the performances of different firms with different backgrounds within the ESG dimension, whereas disclosure of definite figures in terms of a number of patents, alternative energy solutions, or a number of generated livelihood opportunities does not.

\subsection{Sample Construction}

\subsubsection{Selecting the Sample for Automotive Industry and Ride-Sharing Services}

There are 31 companies within the Auto and Truck Manufacturing industry on the Forbes Global 2000 list of 2019. We took the ranking of 2019 because it was the last available year that included classification not only within sectors but also within industries for the listed companies. For the ranking, Forbes uses data from the FactSet Research systems to screen for the biggest public companies over four metrics-sales, profits, assets and market value-from the latest 12-month financial data available. All figures are consolidated in U.S. dollars. The ranking methodology required the creation of four separate lists of the 2000 biggest companies across each of the metrics. Then, each of the four 2000 lists had a minimum cutoff value for a company to qualify: sales $\$ 4.47$ billion, profits of $\$ 333.3$ million, assets of $\$ 10.72$ billion and market value of $\$ 6.55$ billion. A company needed to qualify for at least one of the lists to be eligible for the final Global 2000 ranking. After qualitative computations, experts provided a final quality control by checking for issues that do not show up in figures but hamper the company's image. Publicly traded subsidiaries for which the parent company consolidates figures were also excluded from the list (for most destinations the consolidation level means control over $50 \%$ or more of the subsidiary's stock) [34].

The next criteria was the commitment of the company to the UN Global Compact. The UN Global Compact has 296 entities within the Automobiles and Parts sector among its participants. Twenty out of 31 companies from the Forbes Global 2000 list joined the Compact. Thus, the dropout rate at this stage was 35.5\%.

The last criteria-the institution's commitment to the BCtA Initiative-was met by neither of the companies. In fact, BCtA now has only two members in transport and logistics that are scaling profitable business solutions for low and middle-income economies, and none of the taxi- or car-sharing platforms are among them.

With this in mind, we focused on the leaders in the Forbes Global 2000 Ranking within the Auto and Truck Manufactures industry. 
The reasons for comparing the automotive industry with ride-sharing services stand on the concept that was first introduced 50 years ago by K. Schwab and H. Kroos, and then developed by K. Schwab and P. Vanham [35]. Stakeholder capitalism is a form of capitalism in which companies do not only optimize short-term profits for shareholders, but seek long-term value creation, by taking into account the needs of all their stakeholders and society at large [35]. Today, for us, this means that the institute of private property is no longer needed. Instead, a "user economy" is introduced. "The world will no longer be the same, capitalism will take a different form, we will have completely new types of property in addition to private and state. The largest multinational companies will take on more social responsibility, they will more actively participate in public life and be responsible for the common good" [36].

This approach is also in line with the concept of "shared consumption" [37]. Sharing economies are becoming a new socio-economic model that revolutionizes our consumption of goods and services. As the real need of a consumer is not to possess a thing (in our case-a vehicle) but to get the value from that thing (in our case-transportation or moving over distances), the institute of private property is greatly under threat. Thus, we have more and more examples in which the consumer's tangible asset (a car) is substituted by the intangible service (transportation as a service-TaaS model). Additionally, ride-sharing platforms are not the only drivers of this shift anymore; car manufacturers are also starting to launch ride-sharing. In 2019, Volkswagen introduced a carsharing service "We Share" in Berlin; in 2021, they continued the initiative in Hamburg, positioning it as "a much-used alternative to public transit" [38]. In 2020, Tesla launched an opportunity to share personal cars with other people by introducing a special feature in its app (a part of Tesla's Network initiative), claiming it "will enable the customers to either provide ride-sharing service in their vehicle, similar to other ride-hailing services or rent out their vehicles to other customers, similar to other crowdsourcing agencies" [39].

So, for the platform companies in this segment, we tried to undertake a review of the leading and most cited rankings to obtain a sample of global ride-sharing companies. Given the connectedness of the planned sample to the specific industry, it was not a surprise to discover that these players in the automobile industry could hardly be found in the platform company rankings, showing controversy between their popularity among consumers and their unlisted, unranked status in parallel. It was decided to use a multi-level analysis and apply it to: (a) 43 platforms compiled by Cusumano, Gawer and Yoffie, ranked as purely transactional or innovative platforms [40]; (b) top 100 digital MNEs according to sales or operating revenue, compiled by the World Investment Report 2017, which analyzed all digital MNEs [41]; and (c) top 100 global digital platforms in 2021 according to market capitalization, compiled by Dr. Holger Schmidt and providing a sample of 100 platform companies [42].

The revealed result was that the ranking by Cusumano et al. introduced only 22 transaction platforms, hypothetically including taxi and ride-hailing companies, that ultimately did not provide data on the number of ranked companies. The listed companies were mostly from the internet content market or e-commerce.

Ranking of digital MNEs by UNCTAD had none of the analyzed companies on their list either. It is of note the reason for which some platform companies, including Uber, were unlisted in the Top Digital MNEs. The reason was that they did not meet the third criteria of the selection: (1) applicability to MNEs (foreign revenues or assets over $10 \%$ of the total, and subsidiaries outside the home economy), (2) listing on stock exchanges worldwide, and (3) provision of relevant information on the geographic distribution of sales. A number of platform companies, due to their virtual presence in the majority of countries and having only the headquarters with no affiliated registration, provide no information on foreign sales or foreign assets.

Finding no taxi or ride-hailing companies in the first two rankings, it was decided to apply the Top 100 global digital platforms according to market capitalization 2021 compiled by Dr. Holger Schmidt, and the required entities for the analysis were finally discovered [43]. 
As of the 2021 ranking, this includes six entities-Uber, Lyft, Didi Chuxing, Ola, Grab, and Yandex (Yandex. Taxi as part of the Yandex company). Given the changeability of the market capitalization of such businesses, we attempted to see the presence of these companies in the ranking of dynamics. The results allowed us to reveal that all six companies were ranked over 5 years in the ranking compiled by Schmidt from 2017 to 2021, with Uber outpacing the others by market value, followed by Didi Chuxing. The final selection of the company used in the analysis resulted from the publicity of the companies' annual reports, with Uber again providing the necessary information. Dissimilarly, for Didi Chuxing, there are no annual reports on the company's official website (the company became public only in 2021) [44]. For these reasons, for the final analysis, we took Lyft-third by market capitalization, with annual reports for 2019 and 2020 available.

\subsubsection{Selecting the Samples for Universities and EdTech Companies}

There are 1118 higher education institutions in the Times Higher Education Impact Ranking 2021 [45]. This number comprises a variety of organizations involved in higher education such as universities, institutes and specialist colleges that provide data on SDG 17 and at least three other SDGs. By number of institutions in the ranking, Canada was represented with 23 universities, Australia with 24, Thailand with 25, Taiwan with 35, Pakistan with 36, Iraq with 37, Brazil and Spain with 38, USA with 45, India and Turkey with 49 , the UK with 50, Japan with 75 and Russia with 76. While the sample displays a bias towards higher levels of developing nation representation, countries with the best scores across all their universities are Australia, the UK and Canada. Institutions from emerging markets have relatively low scores.

The next criteria, as with the auto industry, was the commitment of the institution to the UN Global Compact. The UN Global Compact has 691 academic institutions among its participants. However, only a few institutions from the Times Higher Education Impact Ranking, defined at a previous stage, have signed on to the Compact. Thus, out of 76 Russian universities, none were in the list; out of 75 Japanese-only 5; out of 50 from the UK-only 10. The dropout rate on this stage was $99 \%$.

Having recognized this discrepancy, we decided to focus on those institutions that had both high scores in the Times Higher Education Impact Ranking (more than 90.0 points) and an active global compact status, and as one more filter, we then checked whether they had a well-developed internationalization strategy, resulting in a high percentage of international students and/or educational programs with partner institutions abroad.

The last criteria-the institution's commitment to the BCtA Initiative-was met by none of the education institutions. In fact, BCtA now has only four members in education that are scaling profitable business solutions for low and middle-income economies, and none of the higher educational institutions or MOOC platforms are among them.

As for the platform companies in this segment, the sampling from the rankings of the platform companies was even more complicated than with regards to taxi and ridehailing companies. None of the rankings analyzing platform companies listed EdTech companies. Therefore, for our study, we selected two companies by three authoritative criteria: (1) availability of data for public access; (2) availability of free educational courses as a solid proof of meeting SDG 4; and (3) number of courses and users registered on the platform. The sample resulted in the selection of EdX and Coursera-two educational platforms with the biggest number of users and provided courses.

\section{Results}

\subsection{What Sustainability Does a Platform Business Model Show?}

A platform business model is a model "focusing on being an interaction provider between supply and demand, focusing on data, and focusing on building alliances and ecosystems" [46].

Preceded by the business context, sustainability refers to "doing business without negatively impacting the environment, community, or society as a whole" [47]. A company 
that includes sustainability in its strategy aims to make a positive impact on at least one of the pillars of sustainability as a general concept, namely, the economy, society or environment [48].

An important disclaimer on sustainability in terms of the subject of this researchplatform companies - should be made. This paper estimates if platform companies from the selected industries meet the UN SDGs in a more efficient way than linear ones. It does not cover the issue of measuring the sustainability of the platform business model as vigorously implemented by miscellaneous types of companies: linear, tech, sharing, platform, etc.

Given the platform companies selected for the analysis, it can be claimed that their platform business models entail sustainability. Referring to Uber and Lyft, they promote accessible transportation; EdX and Coursera disseminate accessible and high-level educational courses.

\subsection{Comparative Analysis of Platform and Linear MNEs in Terms of Meeting SDGs}

We have studied the Forbes Global 2000 list of 2019. It was comprised of 10 sectors with 82 industries. Out of these 82 industries we selected 50-only those that were represented by at least 10 companies. Then, we studied the ESG corporate reports of 2 companies from each of the 50 industries for the latest year available, in order to make general estimations on how these companies contribute (or to be more precise: claim that they contribute) to SDGs. The results are presented below:

SDG 1 -No poverty-equal pay and safety working conditions, no bounded labor/slavery in the supply chain, generation of livelihood opportunities.

SDG 2-Zero hunger-reduction of food waste and loss, capacity building and sharing of knowledge on sustainable agriculture.

SDG 3-Good health and well-being-support to national health systems, providing affordable healthcare options to employees.

SDG 4-Quality education-vocational, training and other educational programs for employees and communities, flexible work options engaging online and offline educational possibilities, support access to childcare for employees with children.

SDG 5-Gender equality-inclusion of gender equality principles in company policies. SDG 6-Clean water and sanitation-development of new technologies and products for better sanitation, improvement of water usage in production processes.

SDG 7-Affordable and clean energy-investments in new (alternative) energy solutions, development of new technologies and processes for lower energy capacity.

SDG 8-Decent work and economic growth-introduction of financial advisory initiatives for employees, improvement of economic inclusion through supply and value chains. SDG 9-Industry, innovation and infrastructure-integration of sustainable, resourceefficient and green practices into business models.

SDG 10-Reduced inequalities-introduction of a fair wage policy, assistance to marginalized groups with employment opportunities.

SDG 11-Sustainable cities and communities-assistance to marginalized groups, including charity options, development of transportation policies for employees and supply chain operations, on-site spatial improvements.

SDG 12-Responsible consumption and production-development of circular models for products, engagement of consumers in sustainable development through benefit plans and knowledge dissemination.

SDG 13-Climate action-investments into and development of new green technologies and processes for a better climate-related impact.

SDG 14-Life below water -introduction of practices for waste collection, reuse and recycling.

SDG 15-Life on land - introduction of practices for waste collection, reuse and recycling. 
SDG 16-Peace, justice and strong institutions-raise awareness of the relevant legislative regulations and codes among employees, implementation of zero-tolerance to bribery and corruption.

SDG 17-Partnership towards goals-better collaboration ties with competitors within the industry, dissemination of knowledge about own best practices in the SDG fields.

To date, more than 18,000 companies (almost twice as many as back in 2019) have declared their readiness to participate in achieving the SDGs by joining the 10 principles of the UN Global Compact [49]. Being the largest global initiative in the field of corporate social responsibility, the Treaty has been a platform since 2000 for promoting the UN's desire to achieve sustainable development goals through the active interaction of multinational businesses. The question remains open concerning the real degree of involvement of all these companies in the processes of reorganizing their management and operational activities to bring them as close as possible to the ideals of the SDGs, since many global firms still consider sustainable development as synonymous to corporate social responsibility (CSR). Additionally, although CSR is implemented, as a rule, in stages, gradually increasing efforts to improve social, environmental and economic indicators of business-i.e., compliance with measures and prudence (to optimize work and avoid negative consequences) $\rightarrow$ optimization and control (including quality management systems and sustainable development) $\rightarrow$ and, finally, integration of environmental and social issues into the business model and value creation-most companies so far associate themselves only with the first and second stages [50-53].

As far as all the companies studied in our research are public, under the pressure of public opinion and national, regional and internationally voiced commitment to SDGs, they all proclaim the importance of the SDGs and give promises to contribute to their achievement. In public reporting, all companies focus mainly on environmental, social, and governance issues that matter most to their business and their stakeholders-customers, employees, regulators, investors, and even urban areas. For platform companies, stakeholders also include platform users.

However, none of the platform companies from our study (Uber, Lyft, edX, Coursera) is a signatory or participant of the UN Global Compact. Still, some of them publish official documentation, indicating their aspirations to meet SDGs.

Thus, Uber has voiced the CEO's commitment to SDGs-mostly focused on SDG 8, 12 and 13, and the Climate Assessment and Performance Report. Both Uber and Lyft prepare environmental, social and corporate governance reports [54-57].

Coursera and EdX mostly deliver commitment through free courses on sustainable development. EdX is also partnering with the SDG Academy- with a focus on SDG 4 and 17.

\subsection{Meeting of SDGs by Companies in the Automotive Industry and Ride-Sharing Services}

The automotive industry is a significant sector of the world economy, with more than $3 \%$ of the global GDP, and is one of the drivers for macroeconomic growth, stability and technological progress in both developed and developing countries, covering many related industries [58].

In 2019, almost 92 million cars were produced worldwide [59]. China, the USA, Japan, and the EU are the largest manufacturers of passenger cars and commercial vehicles [60]. This reflects that fact that over the past decade, the competitive scenario in the automotive industry has changed dramatically. If until 2010 the world leader in the production of motor vehicles was the European Union, with a global share of more than $30 \%$, since the beginning of 2010 the EU has lost its primacy to China [61]. These changes also directly affect the group of manufacturing companies. At the moment, three conglomerates are leading: the Volkswagen Group (12.2\% of the global market), Toyota Group (11.4\%) and Renault-Nissan-Mitsubishi Alliance (10.8\%) [62].

For the choice of the linear companies sample, we followed three criteria, outlined in Section 2. As none of the top auto companies listed in Forbes Global 2000 were among the 
signatories of the BCtA Initiative, we focused on the two leaders in the Forbes Global 2000 Ranking within the Auto and Truck Manufacturing industry who also signed under the UN Global Compact. These companies are Toyota (\#15 in the Forbes list) and Volkswagen (\#18).

Toyota Motor Corp., the leading manufacturer of motor vehicles and parts by market value (\$176.6 billion); it is a Japanese company founded in 1937 , operating in a variety of segments: (1) automotive-design, manufacturing, assembling and sales of passenger and commercial vehicles, related parts and accessories; (2) IT-development of intelligent transport systems; (3) financial services-purchase or lease financing to dealers and customers along with retail leasing; and (4) other segments-telecommunications, sales of housing, etc.

Even though Toyota, along with the producers of high-class cars, such as Ferrari, Porsche and Tesla, and the majority of Chinese manufacturers, has not expressed a commitment to the Global Compact, it is actively performing in other reporting formats. Since 1999, Toyota has published Environmental Reports, and since 2002, Sustainability Data Books [63]. In 2016, the company introduced the CDP Supply Chain Program to support continuous environmental initiatives (reduction of greenhouse gas emissions, water resource conservation and protection of forests) conducted with suppliers. For the 2020 assessment, the company got an A score (the highest possible) for climate change and water security issues [64].

Toyota is attempting to become carbon neutral via both energy-saving and the introduction of renewable energy and the utilization of hydrogen, with the aim of achieving zero carbon emissions from all global plants by 2050.

Volkswagen AG, the leading European manufacturer of motor vehicles and parts, has a market value of $\$ 91.9$ billion. Like Toyota, it was founded in 1937, and now operates in a variety of areas: (1) automotive-design, manufacturing, assembling and sales of passenger and commercial vehicles, related parts and accessories both for Volkswagen and other brands of the group; (2) power engineering-development and production of large-bore diesel engines, turbo compressors, industrial turbines, chemical reactor systems, gear units, propulsion components and testing systems; and (3) financial services-dealer and customer financing, leasing, banking, insurance, fleet management services, etc.

Unlike Toyota, Volkswagen has been an active UN Global Compact participant since 2002.

Since 2017, it has published Group Sustainability Reports with information on aspects of employee, environmental and social matters, human rights and ethical codes [65]. It is also on the A list of the CDP Program 2020 for water security issues and on the A-list for climate change issues [64].

Volkswagen is attempting to reduce total carbon emissions via its climate-neutral e-mobility program, which requires decarbonization of both the production and supply chain. From 2030, all plants worldwide, other than in China, are to operate entirely on green electricity.

As the automotive industry is heavily exposed to carbon emission issues, both Toyota and Volkswagen seriously consider reporting on SDG achievement progress. In general, their reporting highlights contributions to the following SDGs:

SDG 7: development of new technologies and processes for lower energy capacity;

SDG 8: information on employees; collective bargaining agreements; employees, receiving regular performance and career development reviews;

SDG 12: proportion of spending on local suppliers; waste disposal;

SDG 13: financial implications and other risks, and opportunities due to climate change; reduction of energy consumption; reduction of GHG emissions;

SDG 16: values, principles, standards and norms of behavior; consulting stakeholders on economic, environmental and social topics; assessment of operations for risks related to corruption; approaches to tax governance; political contributions;

SDG 17: mechanisms for advice and concerns about ethics. 
Gradual shifts from car ownership to the Transportation-as-a-Service model require investigation into the leading ride-sharing providers. As already outlined in Section 2, we examined Uber and Lyft as platform companies. Uber, founded back in 2009, is now the leading global ride-sharing service. In 2019 Uber went public. In its mission statement, Uber positions itself as "a tech company whose mission is to help power movement of both people and things", providing ride options, food delivery, and freight services in more than 70 countries [66]. It has more than 100 million active platform consumers and $\$ 92$ billion in annualized run-rate gross bookings across all platforms [55].

In all its reporting and public positioning, Uber states its commitment to sustainable development. Thus, it responds to standards of the Sustainability Accounting Standards Board (SASB), the Task Force on Climate-related Financial Disclosures (TCFD), and the ESG. However, when studied in detail, the company mostly commits to climate-related issues-although with some attention to SDGs 8, 10 and 11 by sharing ideas and taking action in fighting racism and reaching full equity, diversity and inclusion, as well as changing transportation policies in cities [56]. However, the biggest company's bet for achieving SDGs is to carry out $100 \%$ of its rides globally in zero-emission vehicles or through micromobility and public transit by 2040.

Lyft, another on-demand ride-sharing service, was founded in 2012 and is now one of the largest multimodal transportation networks in the United States and Canada, with over two million rides per month. Like Uber, it went public in 2019. Registered revenues in 2020 dropped to $\$ 2.4$ billion from a record $\$ 3.6$ billion in 2019 [67].

As with all the companies in this segment, Lyft focuses mostly on its contribution to reduced emissions by supporting a car-free lifestyle. However, as with Uber, Lyft feasibly assists with SDG 8, 10 and 11 by sharing full equity and its diversity approach, supporting low-income communities and helping to improve city communities. By 2030, the company is planning to have $100 \%$ electric vehicles in its network [57].

A comparative assessment of the two selected car manufacturers and two ride-sharing platforms with regards to the SDG Impact Standards for Enterprises [31] is presented in Table 1.

Table 1. SDG Impact Standards for Enterprises. Assessment of car manufacturers and ride-sharing platforms.

\begin{tabular}{|c|c|c|c|c|c|}
\hline \multicolumn{2}{|c|}{ Requirements' Dimension * } & \multirow[t]{2}{*}{ Uber } & \multirow[t]{2}{*}{ Lyft } & \multirow[t]{2}{*}{ Volkswagen } & \multirow[t]{2}{*}{ Toyota } \\
\hline & 1.1 & & & & \\
\hline 1. Strategy & 1.2 & & & & \\
\hline \multirow{3}{*}{ 2. Management } & 2.1 & & & & \\
\hline & 2.2 & & & & \\
\hline & 2.3 & & & & \\
\hline \multirow{6}{*}{ 3. Transparency } & 3.1 & & & & \\
\hline & 3.2 & & & & \\
\hline & 3.3 & & & & \\
\hline & 3.4 & & & & \\
\hline & 3.5 & & & & \\
\hline & 3.6 & & & & \\
\hline \multirow{3}{*}{ 4. Governance } & 4.1 & & & & \\
\hline & 4.2 & & & & \\
\hline & 4.3 & & & & \\
\hline
\end{tabular}

We classify the degree of commitment showcased for every given indicator by whether: (a) no information is disclosed; (b) minimal information (commitment announced, but no supporting data is disclosed); (c) partial information (commitment announced, but supporting data is disclosed only in CEO interviews); (d) almost full information (commitment announced, supporting data is disclosed in CEO interviews and official corporate statements and initiatives); (e) full information (commitment announced, supporting data is disclosed in CEO interviews, official corporate statements and initiatives, and annual reports). 
In the Table, the assessment carried out using this logic is visualized, where minimum (red color) stands for no information, and maximum (green color) stands for full information disclosure.

\subsection{Meeting of SDGs by Universities and EdTech Companies}

Holon IQ forecasts that the global education market is to reach more than $\$ 10$ trillion by 2030, due to population growth in developing countries and re-skilling and up-skilling demand in developed economies [68]. As almost 1.3 billion people are projected to reach working age in the next 10 years, and as Asia and Africa will contribute mostly to this growth, education as an industry is turning into a prominent player in the SDG 'win-wingame' [69].

Most tertiary educational institutions fall into SDG 4 as they all, at least in public opinion, ensure inclusive and equitable quality education and the promotion of lifelong learning opportunities for all. According to the UNESCO Institute for Statistics, the world average for gross enrollment ratio for tertiary education (SDG 4.3.2) in 2020 was only $40.24 \%$, with large disparities between countries: less than 10\% for Sub-Saharan African countries and more than $85 \%$ in Northern America and Europe [70].

Simultaneously, they contribute to SDG 5 by empowering equal gender opportunities in education. What is more important, global gender balance in higher education is shifting towards female rather than male (as it is in previous educational levels); however, gender equity within science, technology, engineering and mathematics (STEM) fields might vary significantly country by country [70-73].

Access to higher educational programs and inequalities in educational attainment among men and women of different socio-economic statuses is a stumbling block for the majority of universities providing on-campus education. However, for education technologies (here and after-EdTech) companies, the fact that they act within the platform model ensures the goal of empowering learners from all over the world to create pathways to a better life through distant access to best (or at least better) learning practices in a variety of fields.

For our study, we obtained publicly available data on EdX and Coursera-two educational platforms with the highest number of users and provided courses.

$\mathrm{EdX}$ is an online educational platform providing more than 3000 courses to more than 35 million users through almost 15,000 instructors. It was founded in 2012 as an initiative of MIT and Harvard for providing open-access courses to a wide panel of learners. Within less than 10 years, edX turned into a global educational provider with its own learning management system (Open edX).

The edX commitment to SDGs goes beyond SDG4 and includes an embrace of sustainable development as a holistic and activist pursuit [74]. By providing better access to knowledge and skill-sets, the platform helps its learners to obtain jobs and career changes.

As with EdX, Coursera was founded in 2012 by two Stanford professors with the mission of providing life-transforming learning experiences to learners around the world. Today, Coursera is the largest player in the field, offering over 3000 courses to more than 92 million users through partnerships with more than 250 universities, non-profit organizations and businesses [75].

By creating greater access to world-class education online, Coursera enables the creation of accessible pathways for learners with different backgrounds and opportunities to secure jobs in transforming environments-thus driving lasting social change. According to the company's own estimations, free access to content on Coursera is equivalent to $\$ 460$ million [75]. Even though Coursera is not in the list of companies that signed under the UN Global Compact, in 2021 it earned the B Corp certification for meeting rigorous standards of social and environmental performance, accountability and transparency [76]. The same year it also converted to a Public Benefit Corporation.

The latest available data from EdX shows that in 2012-2016, 67\% of their learners were men and 33\% women [77]. The share of overall enrollments from women on Coursera 
globally increased from 38\% in 2018-2019 to 45\% in 2020. For STEM courses, which teach many high-demand digital skills, enrollments among women grew from 31\% in 2018-2019 to $38 \%$ in 2020 [78].

For better comparison, we have chosen two universities that meet the following criteria:

(1) University is ranked in the Times Higher Education Impact Ranking, which assesses more than 1100 universities from 94 countries on action taken towards the UN SDGs.

(2) University has signed onto the UN Global Compact, as the world's largest corporate responsibility initiative.

(3) University has an international student body and educational programs with partner institutions abroad.

The first university that meets all three of these criteria is the University of Manchester, UK. It was the first university in the UK to set social responsibility as its core goal. Today, the University is playing a leading role in tackling SDGs in four ways: (1) research impact through publications, partnerships and collaborations; (2) teaching through providing accessible education to different communities globally and building social responsibility opportunities into the curriculum; (3) public engagement activity in order to involve and inspire local and global communities with SDGs; (4) responsible campus processes, operations and policies [79].

Since 8 April 2019, the University is a member of the UN Global Compact as part of its respect for human rights, the labor environment and anti-corruption [80].

In the Times Higher Education Impact Ranking 2021 the University of Manchester ranked number 1, with the best scores for SDGs 9, 11, 12 and 17.

The University of Manchester has over 10,000 international students enrolled from almost 160 countries.

The RMIT University, Australia, has been a participant of the UN Global Compact since September 17, 2003 [81].

In the Times Higher Education Impact Ranking 2021, the RMIT University ranked number 3, with the best scores for SDGs 8, 9, 10 and 17.

RMIT has exchange programs with more than 150 partner institutions on three continents and almost a quarter of its 30,000 students are international ones.

A comparative assessment of the selected four educational bodies within the SDG Impact Standards for Enterprises [31] is presented in Table 2. As with Table 1, we classify the degree of commitment showcased for every given indicator from minimum (no information is disclosed) to maximum (full information is disclosed).

Table 2. SDG Impact Standards for Enterprises. Assessment of universities and EdTech companies.

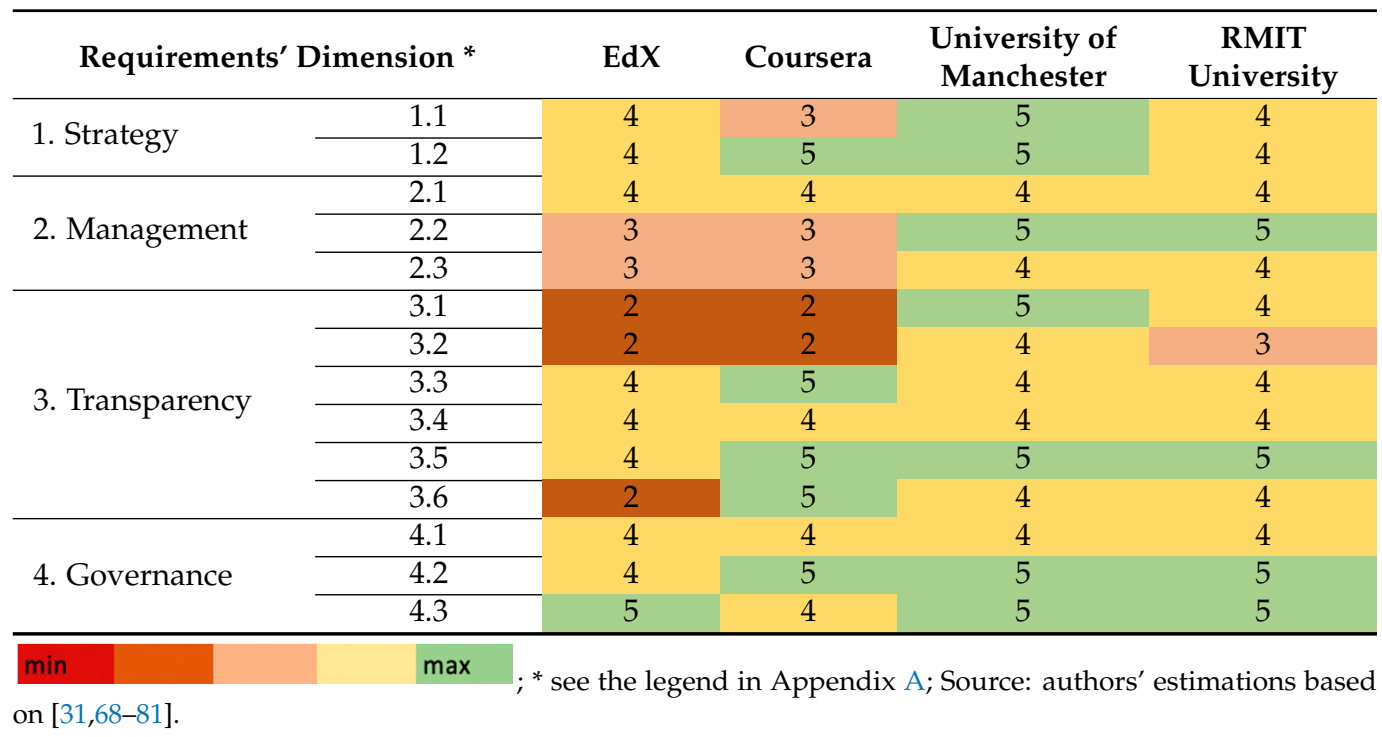




\section{Discussion}

Platform companies entered the market at the beginning of the second decade of the 21st century, and despite the fact that they were able to gain very serious positions in the market within just ten years and become competitors for many linear transnational firms that have been on the market for many decades, they are still in the first stage of the evolution of their management system and interaction with the external environment. The evolution of positioning in relation to sustainable development goals has taken linear companies more than fifty years, starting with the report "Limits of Growth" by the Club of Rome and the report of the Bruntland Commission of 1987 [82,83].

The fact that linear companies still play a very important role in the economy and in the life of society, while platform companies are rapidly strengthening their positions and successfully competing with linear ones-often taking away customers and resources from them by creating new markets and implementing the principles of stakeholder capitalismurges many stakeholders to carefully observe and try to evaluate the results of their activities not only in terms of economic efficiency, but also their consequences and contribution to a wide range of issues of concern to society-one of which is undoubtedly the achievement of SDGs [7-21].

Public institutions, the academic community, and government agencies are trying to understand, systematize and evaluate the impact of business structures (both linear and platform) on the achievement of SDGs. The methodology proposed in this paper for assessing companies' commitment to achieving SDGs is a contribution to the development of tools for assessing the readiness of platform companies to commit themselves to the promotion of critically important issues for society [22-33].

The assessment of companies' commitment to achieving SDGs remains debatable. Further elaboration is required on whether commitment can be considered as a starting point for assessing the real desire of companies to contribute to the implementation of SDGs, and on which indicators or other tools can be used for an objective assessment of this.

A separate issue, nevertheless closely related to the proposed model, is the assessment of the real contribution of platform companies to the achievement of SDGs. As was indicated, researchers have already addressed the topic of the methodology for assessing the contribution of the platform/sharing/collaborative economy, or its individual representatives, and its testing on individual country cases, e.g., [21].

In our opinion, it is fundamentally important to assess the correlation between the level of demonstrated commitment to achieving SDGs and the actual contribution to its achievement. This analysis seems to be multi-factorial, starting from the confirmation of the real relationship between these variables, and ending with the determination of specific indicators of the propensity of firms belonging to different industries, countries, etc., to deviate from the fulfillment of their declared commitment.

\section{Conclusions}

The proposed model for assessing the commitment of platform companies to achieving SDGs integrates the results obtained in the framework of theoretical interdisciplinary research and practical developments in the framework of public discussions-primarily under the auspices of UN institutions.

The proposed methodology makes it possible to assess the degree of commitment of platform firms to achieving SDGs by four parameters: Strategy, Management, Transparency and Governance. This allows us to comprehensively determine, on the basis of open data, the degree of declared (and simultaneously open to public evaluation) data and the commitment, or at least the declaration of commitment, to SDGs by platform firms. Such an assessment is extremely important in terms of the future development of companies strategic goals and values that are pledged by their senior decision makers. 
This methodology is based on indicators that can be estimated for most platform enterprises based on open data. Thus, it allows us to make an independent assessment of the company's commitment (declared or real) to achieving sustainable development goals. Such an assessment, in turn, enables the analysis of the company's achievements in SDGs-taking into account intentions to advance or follow instructions for achieving sustainability. This is of fundamental importance, since, at least at the current stage, the commitment to SDGs in most cases is still taken on a non-regulatory basis.

The conducted testing of the model, based on selected cases, confirmed the assumption that platform companies demonstrate less commitment to SDGs. These results are in line with data previously obtained by researchers that, despite the digital nature of platform companies, they are currently unable to confirm a high efficiency of their business model in terms of contributing to the achievement of SDGs, in contrast to their effectiveness within financial indicators.

Author Contributions: Conceptualization-I.M., Methodology-E.I., Investigation and data curationI.M., O.B., M.B., E.I. Formal analysis-O.B., I.M., M.B., E.I. Writing—original draft preparation, M.B., I.M., O.B., E.I. Writing-editing, M.B., I.M., E.N. All authors have read and agreed to the published version of the manuscript.

Funding: The research is partially funded by the Ministry of Science and Higher Education of the Russian Federation under the strategic academic leadership program 'Priority 2030' (Agreement 075-15-2021-1333 dated 30 September 2021).

Institutional Review Board Statement: Not applicable.

Informed Consent Statement: Not applicable.

Data Availability Statement: Not applicable.

Conflicts of Interest: The authors declare no conflict of interest.

\section{Appendix A}

Table A1. SDG Impact Standards for Enterprises' criteria.

\begin{tabular}{lll}
\hline Standard & \multicolumn{1}{c}{ Dimension } \\
\hline 1. Strategy & 1.1 & $\begin{array}{l}\text { The Enterprise embeds positive contributions to sustainable development and } \\
\text { SDGs into its purpose and strategy }\end{array}$ \\
\cline { 2 - 3 } & 1.2 & $\begin{array}{l}\text { The Enterprise sets ambitious impact goals aligned with its purpose and } \\
\text { strategy }\end{array}$ \\
\hline 2. Management & 2.1 & $\begin{array}{l}\text { The enterprise has effective processes and other mechanisms to deliver on its } \\
\text { strategy and impact goals. }\end{array}$ \\
\cline { 2 - 4 } & 2.2 & $\begin{array}{l}\text { The enterprise assesses and compares the tangible positive and negative } \\
\text { impacts associated with its products, services and operations, and makes } \\
\text { choices between options to optimize its contribution to sustainable } \\
\text { development and SDGs, in line with its impact goals. }\end{array}$ \\
\hline & 2.3 & $\begin{array}{l}\text { The enterprise systematically monitors and manages its ongoing impacts and } \\
\text { acts to optimize its contributions to sustainable development and SDGs } \\
\text { (including managing unexpected outcomes). }\end{array}$ \\
\hline
\end{tabular}


Table A1. Cont.

Standard Dimension

3.1

The enterprise discloses how sustainability and contributing positively to SDGs is integrated into decision making and reports (at least annually) on its performance, in line with the Sustainable Development Goal Disclosure (SDGD) Recommendations.

The enterprise communicates its impacts consistently by using SDGs and ABC Impact Classifications, etc.

The enterprise implements reporting mechanisms to meet the needs of stakeholders affected by its activities and the civil society organizations that act on their behalf, including considering additional non-public, tailored reporting or changes to existing public reporting to make disclosures more

3. Transparency relevant and accessible to a broader range of stakeholders.

The enterprise makes its policies concerning respect for human rights publicly available, in line with the UNGPs, planetary boundaries in line with science-based targets, and other responsible business practices in line with the UNGC's Ten Principles and the UN's Women's Empowerment Principles, and discloses how it implements and manages its performance and conformance. The enterprise complies with relevant laws and regulations regarding social, environmental and governance disclosures.

The enterprise has its external sustainability and/or impact-related reporting verified by an independent third party (or otherwise explains why it has selected not to) and follows up findings with suitable rectification measures in a timely way. governance standards.

4. Governance

The enterprise's parent and/or holding company-including its ultimate holding company-has policies, practices and performance relating to corporate governance, respect for human rights in line with the UNGPs, planetary boundaries in line with science-based targets, and other responsible business practices in line with UNGC's Ten Principles and the UN's Women's Empowerment Principles, that are consistent with the requirements set out in these standards.

\section{References}

1. United Nations. Millennium Development Goals. Available online: https:/ /www.un.org/millenniumgoals / (accessed on 28 October 2021).

2. United Nations Development Programme. Business Call to Action. 2021. Available online: https://www.businesscalltoaction.org (accessed on 28 October 2021).

3. United Nations. SDGs. Available online: https://sdgs.un.org/ (accessed on 23 October 2021).

4. United Nations Development Group. A Million Voices: The World We Want; United Nations: New York, NY, USA, 2013.

5. United Nations News Centre. UN Forum Highlights ‘Fundamental' Role of Private Sector in Advancing New Global Goals. Available online: https:/ /news.un.org/en/story / 2015/09/509862-un-forum-highlights-fundamental-role-private-sector-advancingnew-global-goals\#.VgcFQmRViko (accessed on 12 September 2021).

6. PriceWaterhouseCoopers. Make It Your Business: Engaging with the Sustainable Development Goals; PriceWaterhouseCoopers: London, UK, 2015.

7. Dunning, J.H.; Fortanier, F. Multinational enterprises and the new development paradigm: Consequences for host country development. Multinatl. Bus. Rev. 2007, 15, 25-46. [CrossRef]

8. Kolk, A.; van Tulder, R. International business, corporate social responsibility and sustainable development. Int. Bus. Rev. 2010, 19, 119-125. [CrossRef]

9. Gomez-Trujillo, A.; Gonzalez-Perez, M. Digital transformation as a strategy to reach sustainability. Smart Sustain. Built Environ. 2021. [CrossRef]

10. Johannes, W.H.; Van der Waal, J.; Thijssens, T.; Maas, K. The innovative contribution of multinational enterprises to the Sustainable Development Goals. J. Clean. Prod. 2021, 285, 125319. [CrossRef] 
11. Van Zanten, J.A.; Van Tulder, R. Multinational Enterprises and the Sustainable Development Goals: An Institutional Approach to Corporate Engagement. J. Int. Bus. Policy 2018, 1, 208-233. [CrossRef]

12. Liou, R.; Rao-Nicholson, R. Multinational enterprises and Sustainable Development Goals: A foreign subsidiary perspective on tackling wicked problems. J. Int. Bus. Policy 2020, 4. [CrossRef]

13. Shah, K.; Arjoon, S. Through Thick and Thin? How Self-determination Drives the Corporate Sustainability Initiatives of Multinational Subsidiaries. Bus. Strategy Environ. 2014, 24, 565-582. [CrossRef]

14. Kolk, A.; Kourula, A.; Pisani, N. Multinational enterprises and the sustainable development goals: What do we know and how to proceed? Transnatl. Corp. 2017, 24, 9-32. [CrossRef]

15. Fuster Morell, M.; Espelt, R.; Cano, M. Sustainable Platform Economy: Connections with the Sustainable Development Goals. Sustainability 2020, 12, 7640. [CrossRef]

16. Fuster Morell, M.; Espelt, R.; Senabre Hidalgo, E. Data for Sustainable Platform Economy: Connections between Platform Models and Sustainable Development Goals. Data 2021, 6, 7. [CrossRef]

17. Mabkhot, M.M.; Ferreira, P.; Maffei, A.; Podržaj, P.; Mądziel, M.; Antonelli, D.; Lanzetta, M.; Barata, J.; Boffa, E.; Finžgar, M.; et al. Mapping Industry 4.0 Enabling Technologies into United Nations Sustainability Development Goals. Sustainability 2021, 13, 2560. [CrossRef]

18. Pedersen, E.; Lüdeke-Freund, F.; Henriques, I.; Seitanidi, M. Toward Collaborative Cross-Sector Business Models for Sustainability. Bus. Soc. 2021, 60, 1039-1058. [CrossRef]

19. Burritt, R.; Christ, K.; Rammal, H.; Schaltegger, S. Multinational Enterprise Strategies for Addressing Sustainability: The Need for Consolidation. J. Bus. Ethics 2020, 164, 389-410. [CrossRef]

20. Chivite Cebolla, M.P.; Jorge Vázquez, J.; Chivite Cebolla, C.M. Collaborative economy, a society service? Involvement with ethics and the common good. Bus. Ethics Environ. Responsib. 2021, 30, 657-674. [CrossRef]

21. Lyaskovskaya, E.; Khudyakova, T. Sharing Economy: For or against Sustainable Development. Sustainability 2021, $13,11056$. [CrossRef]

22. World Economic Forum. Toward Common Metrics and Consistent Reporting of Sustainable Value Creation. Available online: https://www3.weforum.org/docs/WEF_IBC_ESG_Metrics_Discussion_Paper.pdf (accessed on 18 December 2021).

23. United Nations Development Programme. Marcos Mancini Nudging the Financial System: A Network Analysis Approach Available online: https://www.fc4s.org/publication/nudging-the-financial-system-a-network-analysis-approach/ (accessed on 18 December 2021)

24. Global Reporting Initiative. About GRI. Available online: https:/ /www.globalreporting.org/about-gri/mission-history/ (accessed on 18 December 2021).

25. Climate Disclosure Standards Board. About CDSB. Available online: https://www.cdsb.net/our-story (accessed on 18 December 2021).

26. AICPA. International Integrated Reporting Council (IIRC). Available online: https://us.aicpa.org/interestareas/ businessindustryandgovernment/resources/sustainability/integratedreporting/ (accessed on 18 December 2021).

27. Sustainability Accounting Standards Board. About Us. Available online: https://www.sasb.org/about/ (accessed on 18 December 2021).

28. Value Reporting Foundation. Transition to Integrated Reporting. A Guide to Getting Started. Available online: https://www. integratedreporting.org/wp-content/uploads/2021/09/Transition-to-integrated-reporting_A-Getting-Started-Guide.pdf/ (accessed on 18 December 2021).

29. International Financial Reporting Standards Foundation. IFRS Foundation Announces International Sustainability Standards Board, Consolidation with CDSB and VRF, and Publication of Prototype Disclosure Requirements. Available online: https:/ / www.ifrs.org/news-and-events/news/2021/11/ifrs-foundation-announces-issb-consolidation-with-cdsb-vrfpublication-of-prototypes/ (accessed on 18 December 2021).

30. United Nations Development Programme. SDG Impact Standards. Available online: https://sdgimpact.undp.org/practicestandards.html (accessed on 12 October 2021).

31. United Nations Development Programme. SDG IMPACT STANDARDS Enterprises. Integrating Impact Management into Enterprises' Decision-Making to Optimize Their Contribution to Sustainable Development and the SDGs. Available online: https://sdgimpact.undp.org/assets/SDG-Impact-Standards-for-Enterprises-DRAFT-for-second-consultation.pdf (accessed on 15 October 2021).

32. Hollyer, J.R.; Rosendorff, B.P.; Vreeland, J.R. Democracy and transparency. J. Politics 2011, 73, 1191-1205. [CrossRef]

33. Cannizzaro, A.P.; Weiner, R.J. State ownership and transparency in foreign direct investment. J. Int. Bus. Stud. 2018, 49, 172-195. [CrossRef]

34. Forbes. Global 2000 Methodology. Available online: https://www.forbes.com/sites/andreamurphy/2018/06/06/2018-global-20 00-methodology-how-we-crunch-the-numbers/?sh=7fe06c111504 (accessed on 28 October 2021).

35. Schwab, K.; Vanham, P. Stakeholder Capitalism: A Global Economy that Works for Progress, People and Planet; John Wiley \& Sons: New York, NY, USA, 2021; ISBN 978-1-119-75613-2.

36. Schwab, K.; Malleret, T. COVID-19: The Great Reset. Available online: https://straight2point.info/wp-content/uploads/2020/0 8/COVID-19_-The-Great-Reset-Klaus-Schwab.pdf (accessed on 20 October 2021). 
37. Botsman, R.; Rogers, R. What's Mine is Yours: How Collaborative Consumption Is Changing the Way We Live; Harper Collins: London, UK, 2011; p. 280. ISBN 978-0-007-41348-5.

38. Volkswagen AG. Volkswagen Begins Electric Car Sharing in Hamburg. Available online: https://www.volkswagenag.com/en/ news/stories/2021/02/volkswagen-begins-electric-car-sharing-in-hamburg.html\# (accessed on 8 October 2021).

39. Mobiag. Musk: Tesla Network Will Be Airbnb of Ride-Sharing. Available online: https://mobiag.com/blog/musk-tesla-networkwill-be-airbnb-of-ride-sharing/ (accessed on 9 October 2021).

40. Cusumano, M.; Gawer, A.; Yoffie, D. The Business of Platforms: Strategy in the Age of Digital Competition, Innovation, and Power, Harper Business: New York, NY, USA, 2019.

41. United Nations Conference on Trade and Development. The Top 100 Digital MNEs. Technical Annex to the World Investment Report 2017 Investment and the Digital Economy; United Nations Publication: New York, NY, USA; Geneva, Switzerland, 2017.

42. United Nations Conference on Trade and Development. Digital Economy Report. 2021. Available online: https://www.unilibrary.org/content/books/9789210058254/read (accessed on 28 October 2021).

43. Netzoekonom. Geographical Distribution of the Top 100 Global Digital Platforms. Available online: http:/ /www.netzoekonom. de/vortraege/\#tab-id-1 (accessed on 28 October 2021).

44. Didi. Investors. Available online: https://ir.didiglobal.com/overview/default.aspx (accessed on 28 October 2021).

45. Times Higher Education. World University Impact Rankings 2021. Available online: https:/ /www.timeshighereducation.com/ impactrankings\#!/page/0/length/25/sort_by/rank/sort_order/asc/cols/undefined (accessed on 28 October 2021).

46. Dotmagazine. Transforming Business Models in the Platform Economy. Available online: https://www.dotmagazine.online/ issues/going-digital/industry-4-0-paving-the-way/business-models-in-the-platform-economy (accessed on 23 October 2021).

47. Spiliakos, A. What Does "Sustainability" Mean in Business? Harvard Business School Online. Available online: https://online. hbs.edu/blog/post/what-is-sustainability-in-business (accessed on 23 October 2021).

48. Barbier, E.B. The Concept of Sustainable Economic Development. Environ. Conserv. 1987, 14, 101-110. [CrossRef]

49. United Nations Global Compact. Our Participants. Available online: https://www.unglobalcompact.org/what-is-gc/participants (accessed on 12 September 2021).

50. Martinuzzi, A.; Krumay, B. The Good, the Bad, and the Successful-How Corporate Social Responsibility Leads to Competitive Advantage and Organizational Transformation. J. Change Manag. 2013, 13, 424-443. [CrossRef]

51. Schönherr, N.; Findler, F.; Martinuzzi, A. Exploring the Interface of CSR and the Sustainable Development Goals. Transnatl. Corporations. 2017, 24, 33-47. [CrossRef]

52. Jiang, C.; Fu, Q. A Win-Win Outcome between Corporate Environmental Performance and Corporate Value: From the Perspective of Stakeholders. Sustainability 2019, 11, 921. [CrossRef]

53. Lee, K.; Lee, H. How Does CSR Activity Affect Sustainable Growth and Value of Corporations? Evidence from Korea. Sustainability 2019, 11, 508. [CrossRef]

54. Uber. CEO's Commitment. Available online: https://www.uber.com/us/en/about/sustainability/ (accessed on 28 October 2021).

55. Uber. Investor Relations. Available online: https://investor.uber.com/home/default.aspx (accessed on 28 October 2021).

56. Uber. ESG Report 2021. Available online: https://s23.q4cdn.com/407969754/files/doc_downloads/2021/07/Uber-2021-ESGReport.pdf (accessed on 1 October 2021).

57. Lyft. ESG Report. 2021. Available online: https://s27.q4cdn.com/263799617/files/doc_financials/2021/ESG/ESG-2021-Report_ Final.pdf (accessed on 28 October 2021).

58. Kearney, A.T. The Contribution of the Automobile Industry to Technology and Value Creation. Available online: https://www.es kearney.com/automotive/article/?/a/the-contribution-of-the-automobile-industry-to-technology-and-value-creation (accessed on 28 October 2021).

59. Statista. Worldwide Automobile Production through 2019. Available online: https://www.statista.com/statistics/262747 /worldwide-automobile-production-since-2000/ (accessed on 28 October 2021).

60. Statista. Leading Car Manufacturing Countries Worldwide 2019. Available online: https://www.statista.com/statistics/584968 /leading-car-manufacturing-countries-worldwide/ (accessed on 28 October 2021).

61. European Automobile Manufacturers' Association. World Motor Vehicle Production. Available online: https://www.acea.be/ statistics/article/world-production (accessed on 28 October 2021).

62. Focus2Move. Global Auto Market. The Ranking by Manufacturer in 2019. Available online: https://focus2move.com/world-cargroup-ranking/ (accessed on 28 October 2021).

63. Toyota. Sustainability Data Book. Available online: https://global.toyota/en/sustainability/report/sdb/ (accessed on 28 October 2021).

64. CDP Supply Chain Program. Companies Scores. 2020. Available online: https://www.cdp.net/en/companies/companies-scores (accessed on 28 October 2021).

65. Volkswagen Sustainability Report 2020. Available online: https://www.volkswagenag.com/en/sustainability/reporting.html (accessed on 28 October 2021).

66. Uber. About Us. Available online: https://www.uber.com/it/en/about/ (accessed on 28 October 2021).

67. Lyft. Annual Report 2020. Available online: https://s27.q4cdn.com/263799617/files/doc_financials/2020/ar/Annual-Report-20 20.pdf (accessed on 28 October 2021). 
68. Holon IQ. Education in 2030. The \$10 Trillion Dollar Question. Available online: https://www.holoniq.com/2030/ (accessed on 28 October 2021).

69. United Nations. World Population Prospects. Available online: https:/ / population.un.org/wpp/ (accessed on 28 October 2021).

70. UNESCO Institute for Statistics. Available online: http:/ / data.uis.unesco.org (accessed on 28 October 2021).

71. Bailey, M.J.; Dynarski, S.M. Gains and Gaps: Changing Inequality in US College Entry and Completion; (Working Paper 17633); National Bureau of Economic Research: Cambridge, MA, USA, 2011; Available online: http://users.nber.org/ \{\}dynarski/ Bailey_Dynarski.pdf (accessed on 28 October 2021).

72. Cahalan, M.; Perna, L. Indicators of Higher Education Equity in the United States. The Pell Institute for the Study of Opportunity in Higher Education and the University of Pennsylvania Alliance for Higher Education and Democracy: USA. 2015. Available online: http://www.pellinstitute.org/downloads/publications-Indicators_of_Higher_Education_Equity_in_the_US_45_Year_ Trend_Report.pdf (accessed on 28 October 2021).

73. American Physical Society. Women in Physics Statistics. Available online: http://www.aps.org/programs/women/resources/ statistics.cfm (accessed on 28 October 2021).

74. UN Sustainable Development Solutions Network. edX Attends SDSN Leadership Council during UNGA Week. Available online: https:/ / www.unsdsn.org/news/2018/10/12/edx-attends-sdsn-leadership-council-during-unga-week3aa21cd7 (accessed on 1 October 2021).

75. Coursera Impact Report 2021. Available online: https://about.coursera.org/press/wp-content/uploads/2021/11/2021 -Coursera-Impact-Report.pdf (accessed on 28 October 2021).

76. B Corps. Available online: https://bcorporation.net/about-b-corps (accessed on 28 October 2021).

77. EdX Blog. Study of MOOCs Offers Insights into Online Learner Engagement and Behavior. Available online: https://blog.edx. org/study-moocs-offers-insights-online-learner-engagement-behavior (accessed on 28 October 2021).

78. Coursera Women and Skills Report 2021. Available online: https://about.coursera.org/press/wp-content/uploads/2021/09/ Coursera-Women-and-Skills-Report-2021.pdf (accessed on 28 October 2021).

79. The University of Manchester SDG. Available online: https:// documents.manchester.ac.uk/display.aspx?DocID=43184 (accessed on 28 October 2021)

80. University of Manchester. SDG Letter of Commitment. Available online: https://ungc-production.s3.us-west-2.amazonaws. com/commitment_letters/135392/original/Secretary-General_United_Nations_26.2.19.pdf?1551718512 (accessed on 28 October 2021).

81. RMIT University Data for UN Global Compact. Available online: https:/ /www.unglobalcompact.org/what-is-gc/participants/ 8028-RMIT-University\#company-information (accessed on 28 October 2021).

82. Meadows, D.H.; Meadows, D.L.; Randers, J.; Behrens III, W.W. Limits of Growth; A Report for the Club of Rome. Project on the Predicament of Humanity; Potomac Associates: Washington, DC, USA, 1972.

83. World Commission on Environment and Development. Our Common Future; Oxford University Press: Oxford, UK, 1987. 